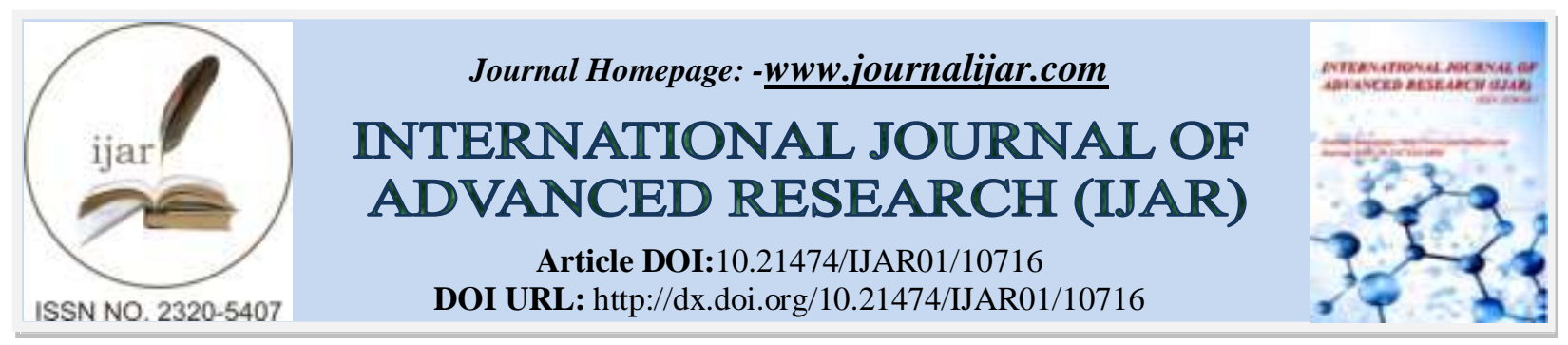

RESEARCH ARTICLE

\title{
RHEUMATOID HAND: CLINICAL, RADIOLOGICAL AND GRIPSTRENGTH ASSESSMENT
}

\author{
Khudhair SA and Al-Sadoon $M$ \\ M.B.Ch.B., Dr. \& Med. Rehab. A Rheumatology Specialist.
}

\section{Manuscript Info}

Manuscript History

Received: 22 January 2020

Final Accepted: 25 February 2020

Published: March 2020

Key words:-

Rheumatoid Hand, Radiological

Finding, Grip Strength

\section{Abstract}

Background:Rheumatoid arthritis is a systemic autoimmune disorder of unknown etiology.Grip force and strength are a common measurement used in the assessment of the hand function

Methodology:Patients of at least two years duration history of rheumatoid arthritis, attending rheumatology unit in the period from October 1995 to April 1996, were included in this descriptive study.Patients with a history of trauma or operation in the hand or wrist joint were excluded.

Results:Female were 83patients $(83 \%)$ and males were 17 patients $(17 \%)$. Deformities in 200 hands were reported which showed. Flexor tenosynovitis was more in the middle (56) and index (53) fingers than in other fingers, and more in the right (103) than the left (75) hand.The grip strength was impaired in all patients. Mild impairment reported in $14 \%$, moderate impairment in $27 \%$ and severely impaired hand grip was seen in $59 \%$ of patients.

Conclusion: Flexor tenosynovitis and subluxation of metacarpophalangeal joints were seen more in the right than the left hand and more in the index and middle fingers than in other fingers. Grip strength assessment is frequently used inclinical trials and is a sensitiveindicator of disease activity.

Copy Right, IJAR, 2020,. All rights reserved.

\section{Introduction:-}

Rheumatoid arthritis is a systemic autoimmune disorder of unknown etiology.Its major distinctive feature is chronic symmetric and erosive synovitis of peripheral joints. An elevated titer of serum Rheumatoid factor was found in $85 \%$ of patients. Associated extra-articular manifestations may include subcutaneous nodules, vasculitis, pericarditis, pulmonary interstitial fibrosis, episcleritis and scleritis ${ }^{(1)}$.

Its prevalence among Iraqi people is $1 \%{ }^{(2)}$.

The articular manifestations of RA can be placed into two categories, reversible signs and symptoms related to inflammatory synovitis and irreversible structural damage brought by synovitis ${ }^{(3)}$.

Among the factors contributing to the development of deformities of the hand arethe articular and periarticular structural changes of RA together with forces involved in the use of the hand ${ }^{(4)(5)}$.

Hakstain and Tubiana emphasized the importance of tissue destruction in the production of deformity and stated that external forces of hand use only have a secondary effect ${ }^{(5)}$. 
Teno-synovitis may often accompany synovitis and spontaneous Rheumatoid tendon rupture may occur which is due primarily to the effect of tenosynovitis on the tendon and secondarily to the effect of tenosynovitis on the bone $^{(6)}$.

Patients with RA in whom articular bone lesions confined to the wrist and/or carpal joints in X-ray films may follow milder disease activity than do the patients with hand and finger joint lesions.

The former patients are milder in disease activity and fewer in No. of affected joints as well as milder in clinical course and have a better prognosis ${ }^{(7)}$.

Grip force and strength are a common measurement used in the assessment of the hand function ${ }^{(8)(9)}$.

The grip can be measured in a variety of ways, the most satisfactory and reproducible being using a rubber bag attached to a sphygmomanometer ${ }^{(10)}$.

The quality of the information gained from grip strength measurement and its interpretation depends on the established reliability of the instruments, and the consistency of test administration ${ }^{(11)}$.

Grip force can be used as an indicator of improvement, for comparing the effectiveness of various treatment procedures and for the assessment of a patient's ability to return to home activities and previous employment ${ }^{(9)}$.

Aim of The Study:

To shed some light on the relationship between clinical and radiological changes of the rheumatoid hand and its function based on grip strength test.

\section{Patients and methods:-}

One hundred patients, 83 females and 17 males with a diagnosis of RA according to (ARA revised 1987 criteria for classification of RA $)^{(12)(9)}$. Patients of at least two years duration, attending rheumatology unit in Baghdad teaching hospital in the period from October 1995 to April 1996, were included in this descriptive study. All patients except one were right-handed. Patients with a history of trauma or operation in the hand or wrist joint were excluded.

Two hundred hands were examined for:

1. Dislocation of the ulnar styloid.

2. Dislocation of the carpal bones.

3. Subluxation of the metacarpophalangeal joints.

4. Correctable ulnar deviation.

5. Uncorrectable ulnar deviation.

6. Swan - neck deformity.

7. Boutonniere deformity.

8. Z-deformity of the thumb.

9. Dropped finger (ruptured extensor tendon).

10. Flexor tenosynovitis: is said to be present if two of the following three criteria are present ${ }^{(13)}$ :

11. Pain, swelling or tenderness along flexor tendon or sheath.

12. Snapping, crepitation, or locking of finger.

13. Difficulty in flexion or extension of finger.

Grip strength of the dominant hand was evaluated for all patients,using a sphygmomanometer and they were grouped into mild, moderate and severe impairment $(<45,45-100,100-180) \mathrm{mmHg}$ for female and $(<55,55-140$, $140-250) \mathrm{mmHg}$ for male ${ }^{(14)}$.

Postero-anterior X-ray films of both hands (including wrists) were taken for 85 patients, and their changes were read by two observers blindly and assigned by Steinbrocker radiographic stage ${ }^{(13)}$.

Stage I: No destructive changes, but periarticular osteoporosis may be present; stage II: osteoporosis and slight cartilage and/or subchondral bone destruction may present; stage III: osteoporosis and cartilage and/or bone destruction; stage IV: stage IIIfinding plus fibrous or bony ankylosis. 
Rheumatoid factor (Latex fixation test) and Erythrocytes sedimentation rate (wester green) was done for all patients.

Statistical analysis:

Chi-square test used to find the relationshipbetween different variables: clinical deformities, radiographic changes, and grip strength impairment.

\section{Results:-}

Characteristics of patients were shown in table-1, where females were 83 patients $(83 \%)$ and males were 17 patients (17\%) with a male to female ratio of 1:4.9.Patients with positive Rheumatoid factors(RF) constituted $69 \%$ of the total patients. The prevalence of positive RF among the two genders was close to each other $(69.9 \%$ and $64.7 \%$ respectively).

Table 1:- Characteristics of patients in the study $(\mathrm{n}=100)$.

\begin{tabular}{|l|l|l|l|}
\hline Variables & Female & Male & Total \\
\cline { 2 - 4 } & $\mathrm{n}(\%)$ & $\mathrm{n}(\%)$ & $\mathrm{n}$ \\
\hline Gender & $83(83)$ & $17(17)$ & 100 \\
\hline Inpatients & 51 & 12 & 63 \\
\hline Outpatients & 32 & 5 & 37 \\
\hline Patients with positive Rheumatoid factor & $58(69.9)$ & $11(64.7)$ & 69 \\
\hline & mean & mean & \\
\hline Mean age (year) & 45.9 & 49.2 & -- \\
\hline Mean diseases duration (year) & 8.6 & 8.4 & -- \\
\hline Mean Erythrocyte Sedimentation rate & 63 & 58 & - \\
\hline
\end{tabular}

\section{Hand deformities:}

Deformities in 200 hands were reported in table 2 which showed a dropped finger was seen only in one patient involving the left middle and ring fingers and the right little finger. Flexor tenosynovitis was more in the middle (56) and index (53) fingers than in other fingers, and more in the right (103) than the left (75) hand.Correctable and uncorrectable ulnar deviation and subluxation of metacarpophalangeal joints were seen only in female patients. According to table-3 dislocation of ulnar styloid was observed in 81 hands (48\%), while dislocation of carpal bones was seen in 10 hands $(5 \%)$.

Table 2:- Rate of occurrence of different types of deformities in fingersof rheumatoid arthritis hands.

\begin{tabular}{|c|c|c|c|c|c|c|c|}
\hline Deformity & & Thumb & Index & Middle & Ring & Little & Total \\
\hline Dropped finger & $\begin{array}{l}\mathrm{Rt} \\
\mathrm{Lt}\end{array}$ & $\begin{array}{l}-- \\
--\end{array}$ & $\begin{array}{l}- \\
--\end{array}$ & $\begin{array}{l}-- \\
1\end{array}$ & $\begin{array}{l}-- \\
1\end{array}$ & $\begin{array}{l}1 \\
--\end{array}$ & $\begin{array}{l}1 \\
2\end{array}$ \\
\hline Swan neck deformity & $\begin{array}{l}\mathrm{Rt} \\
\mathrm{Lt}\end{array}$ & -- & $\begin{array}{l}11 \\
7\end{array}$ & $\begin{array}{l}11 \\
7\end{array}$ & $\begin{array}{l}6 \\
7\end{array}$ & $\begin{array}{l}9 \\
7\end{array}$ & $\begin{array}{l}37 \\
28\end{array}$ \\
\hline Boutonniere deformity & $\begin{array}{l}\mathrm{Rt} \\
\mathrm{Lt}\end{array}$ & $\begin{array}{l}-- \\
--\end{array}$ & -- & $\begin{array}{l}1 \\
2\end{array}$ & $\begin{array}{l}4 \\
4\end{array}$ & $\begin{array}{l}4 \\
2\end{array}$ & $\begin{array}{l}9 \\
8\end{array}$ \\
\hline Flexor tenosynovitis & $\begin{array}{l}\mathrm{Rt} \\
\mathrm{Lt}\end{array}$ & $\begin{array}{l}4 \\
1\end{array}$ & $\begin{array}{l}29 \\
40\end{array}$ & $\begin{array}{l}34 \\
22\end{array}$ & $\begin{array}{l}26 \\
18\end{array}$ & $\begin{array}{l}10 \\
10\end{array}$ & $\begin{array}{l}103 \\
75\end{array}$ \\
\hline $\begin{array}{ll}\text { Correctable ulnar } \\
\text { deviation }\end{array}$ & $\begin{array}{l}\mathrm{Rt} \\
\mathrm{Lt}\end{array}$ & $\begin{array}{l}- \\
--\end{array}$ & $\begin{array}{l}10 \\
9\end{array}$ & $\begin{array}{l}9 \\
7\end{array}$ & $\begin{array}{l}7 \\
8 \\
\end{array}$ & $\begin{array}{l}6 \\
8\end{array}$ & $\begin{array}{l}32 \\
32\end{array}$ \\
\hline $\begin{array}{l}\text { Uncorrectable ulnar } \\
\text { deviation }\end{array}$ & $\begin{array}{l}\mathrm{Rt} \\
\mathrm{Lt}\end{array}$ & $\begin{array}{l}-- \\
--\end{array}$ & $\begin{array}{l}13 \\
11\end{array}$ & $\begin{array}{l}15 \\
13\end{array}$ & $\begin{array}{l}14 \\
13\end{array}$ & $\begin{array}{l}12 \\
13\end{array}$ & $\begin{array}{l}54 \\
55\end{array}$ \\
\hline Subluxation of MCP joint & $\begin{array}{l}\mathrm{Rt} \\
\mathrm{Lt}\end{array}$ & $\begin{array}{l}- \\
--\end{array}$ & $\begin{array}{l}20 \\
17\end{array}$ & $\begin{array}{l}20 \\
15\end{array}$ & $\begin{array}{l}18 \\
10\end{array}$ & $\begin{array}{l}13 \\
10\end{array}$ & $\begin{array}{l}71 \\
52\end{array}$ \\
\hline $\mathrm{Z}$ deformity of thumb & $\begin{array}{l}\mathrm{Rt} \\
\mathrm{Lt}\end{array}$ & $\begin{array}{l}14 \\
10 \\
\end{array}$ & $\begin{array}{l}- \\
-- \\
\end{array}$ & $\begin{array}{l}-- \\
--\end{array}$ & -- & $\begin{array}{l}-- \\
-- \\
\end{array}$ & $\begin{array}{l}14 \\
10 \\
\end{array}$ \\
\hline
\end{tabular}

Table 3:- Prevalence of dislocation of ulnar styloid and carpal bones in study patients.

\begin{tabular}{|l|l|l|l|}
\hline Deformity & Right hand & Left hand & Total \\
\hline Dislocation of ulnar styloid & 43 & 38 & 81 \\
\hline Dislocation of Carpal bones & 5 & 5 & 10 \\
\hline
\end{tabular}




\section{Radiographic finding:}

Out of the 85 patients, only four did not show periarticular osteoporosis two were males, one of them had erosion in one site and two were females both of them had erosions in multiple sites.Radiographic stage III was the commonest, seen in $31.7 \%$. Radiographic stage I, II and IV were seen in $25.8 \%, 15.2 \%$ and $27 \%$ of the patients respectively as shown in (table 4 ).

Table 4:- Radiographic staging of rheumatoid arthritis patients' hand.

\begin{tabular}{|l|l|l|}
\hline Radiographic stage $(\mathbf{n}=\mathbf{8 5})$ & No of patients & $\mathbf{\%}$ \\
\hline Stage I & 22 & 25.8 \\
\hline Stage II & 13 & 15.2 \\
\hline Stage III & 27 & 31.7 \\
\hline Stage IV & 23 & 27 \\
\hline Total & 85 & 100 \\
\hline
\end{tabular}

\section{Hand grip strength:}

The grip strength was impaired in all patients.Mild impairment reported in $14 \%$, moderate impairment in $27 \%$ and severely impaired hand grip was seen in 59\% of patients.

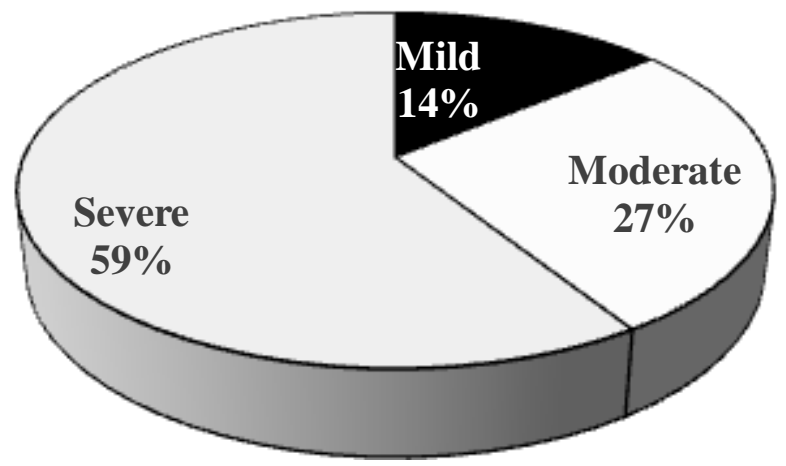

Figure-1:- Hand grip strength impairment.

Severe radiographic destructive changes (stage IV) was seen in 23 patients (27\%), 15 of these patients had severe impairment of handgrip strength. The study shows a significant relationship between the hand radiographic stage and severityof grip strength impairment as shown in table-5.

Table 5:- Relationship between radiographic changes stages and severity of hand grip strength impairment.

\begin{tabular}{|c|c|c|c|c|c|}
\hline \multirow[t]{2}{*}{ Radiographic stage $(\mathrm{N}=8 \mathbf{5})$} & \multicolumn{4}{|c|}{ Hand grip strength impairment } & \multirow{2}{*}{$\begin{array}{l}\text { Chi-square test } \\
\text { P-value }\end{array}$} \\
\hline & Mild & Moderate & Severe & Total & \\
\hline Stage I & 7 & 7 & 8 & 22 & \multirow{5}{*}{$\begin{array}{l}X^{2}=54.21 \\
P \text {-value }<0.005\end{array}$} \\
\hline Stage II & 1 & 6 & 6 & 13 & \\
\hline Stage III & 1 & 5 & 21 & 27 & \\
\hline Stage IV & 3 & 5 & 15 & 23 & \\
\hline Total & 12 & 23 & 50 & 85 & \\
\hline
\end{tabular}

The study also showed no significant relationship between hand deformities and severity of handgrip strength impairment (table 6).

Table 6:- Relationship between hand deformities and handgrip strength impairment.

\begin{tabular}{|l|l|l|l|l|l|}
\hline \multirow{2}{*}{ Types of deformity } & \multicolumn{3}{|l|}{ Hand grip strength impairment } & \multicolumn{2}{l|}{$\begin{array}{l}\text { Chi-sq test } \\
\text { P-value }\end{array}$} \\
\cline { 2 - 6 } & Mild & Moderate & Severe & Total & X-27 \\
\hline Dislocation of ulnar styloid & 6 & 15 & 27 & 48 & $\mathrm{X}^{2}=23.87$ \\
\hline
\end{tabular}




\begin{tabular}{|c|c|c|c|c|c|}
\hline Dislocation of carpal bones & -- & 3 & 2 & 5 & \multirow{9}{*}{$\mathrm{P}>0.05^{*}$} \\
\hline Dropped finger & -- & -- & 1 & 1 & \\
\hline Flexor tenosynovitis & 5 & 14 & 25 & 44 & \\
\hline Correctable ulnar deviation & 3 & 4 & 5 & 12 & \\
\hline Uncorrectable ulnar deviation & 1 & 2 & 12 & 15 & \\
\hline Swan neck deformity & 3 & 2 & 14 & 19 & \\
\hline Boutonniere deformity & 1 & 2 & 8 & 11 & \\
\hline Z-deformity of thumb & 3 & 3 & 8 & 14 & \\
\hline Subluxation of MCP joint & 2 & 2 & 18 & 22 & \\
\hline
\end{tabular}

\section{Discussion:-}

Grip strength assessment is frequently used inclinical trials and is a sensitiveindicator of disease activity ${ }^{(8)}$. Varying the position of the forearm altered the strength of the grip ${ }^{(11)}$.Patients with rheumatoid arthritis had approximately a $75 \%$ reduction inmaximum grip strength ${ }^{(8)}$.

Ulnar styloid dislocation was the commonest deformity observed (4\%) followed by flexor tenosynovitis (44\%). Only one patient had a dropped finger. The patient was female, with the seropositive disease for 12 years. Flexor tenosynovitis and subluxation of metacarpophalangeal joints were seen more in the right than the left hand and more in the index and middle fingers than in other fingers and this possibly due to excessive use of these two fingers during hand function and so greater muscles pull on the metacarpophalangeal joints of these fingers ${ }^{(4)}$.

The prevalence of correctable and uncorrectable ulnar deviation swan-neck deformity, boutonniere deformity and flexor tenosynovitis in this study was compared with Mody et al. study ${ }^{(4)}$,correctable and uncorrectable ulnar deviation and subluxation of metacarpophalangeal joints were seen only in' female patients. The possible explanations are a relatively little number of male patients in this study and probably excessive use of the hand in homework by female patients.

Radiographic stage III was the commonest in the current study group while stage IV was the commonest group $33.3 \%$ in Regn-Smith et al. study, stage I was higher in our study than that reported by Regn-Smith et al. which was $14.8 \%{ }^{(15)}$.

\section{References:-}

1. Wilder, RL. Epidemiology, pathology and pathogenesis of Rheumatoid Arthritis In: Primer on Rheumatic diseases, $10^{\text {th }}$ ed.; Arthritis. Foundation Atlanta, Georgia 1993, 86-89.

2. AL-Rawi, ZS., Al-Azzawi, AJ., Al-Ajili, FM., Al-Wakil, R. Rheumatoid arthritis in population sample in Iraqi. Ann Rheum Dis. 1978;37:73-5.

3. Anderson, RL., Clinical feature of Rheumatoid arthritis, In: Primer on Rheumatic diseases $10^{\text {th }}$ ed.; Arthritis Foundation, Atlanta, Georgia, 1993, pp. 90-95.

4. Mody, GM., Meyers, OL., Reinach, SG. Handedness and deformities, radiological changes and function of the hand in Rheumatoid arthritis. Ann Rheum Dis 1989; 48:104-107.

5. Hakstain, RW., Tubiana, R. Ulnar deviation of the fingers. The role of joint structure and function. Bone and joint surgery. 1967; 49:299-316.

6. Lesile, BM. Rheumatoid extensor tendon rupture. Hand Clinic. Tufts University, Boston 1989; $191-202$.

7. Yoshioka, k., Takano, S., Yasuda, M., Nobunaga, M. Evaluation of disease activities of hand by X-ray finding. Ryumachi 1989; 29(2):105-9.

8. Helliwell, P., Howe, A., Wright, V. Functional assessment of the hand: reproducibility, acceptability, and utility of a new system for measuring strength. Annals of the Rheumatic Diseases, 1987; 46, 203-208

9. Nordenskiold, UM., Grimby, G. Grip force in patients with Rheumatoid arthritis and fibromayalgia and in healthy subjects. A study with Gripit instrument. Scand J Rheumatol. 1993;22:14-19.

10. Ansell, BM. Hand assessment in rheumatoid arthritis. Ann. rheum. Dis. 1969; 28s: PP. 77.

11. Richards, LG., Olson, B., Palmiter-Thomas, P. How forearm positionaffectsgrip strength. The American J

12. Occupat Therapy.1996;50(2):133-138. 
13. Arnett, FC., Edworthy, SM., Bloch, DA., McShane, DJ., Fries, JF., Cooper, NS., et al. The American Rheumatism association 1987 revised criteria for classification of Rheumatoid arthritis. Arthritis Rheum. 1989;31(3):315-24.

14. Gray, RG., Gottieb, NL. Hand flexor tenosynovitis in rheumatoid arthritis, prevalence, distribution and

15. associated rheumatic feature. Arthritis Rheum. 1977;20:1003-1008.

16. Hess, EV. Treatment of rheumatoid arthritis. In: Primer on the rheumatic diseases. $9^{\text {th }}$ ed. Arthritis foundation, Atlanta, Gorgea. 1988, pp.93-96.

17. Regn-Smith MG., O’Connor GT., Kwoh, CK., Brown, LA., Olmstead, EM., Burnett, B. Lack of correlation

18. between steinbroclcer staging of hand radiograph and the functional health status of individual with rheumatoid 19. arthritis. Arthritis Rheum. 1989;32(2):128-133. 